\title{
Possible routes for Conservation and Restoration in the risk management of Built Heritage: public-private partnerships within R\&D projects (Project STORM)
}

\author{
Nuno Proença ${ }^{1, *}$ \\ Maria João Revez ${ }^{1}$ (D) \\ ${ }^{1}$ Nova Conservação, Lda., Largo Vitorino Damásio, 3, 3. Esq., 1200-872 Lisboa, Portugal \\ *nunoproenca@ncrestauro.pt
}

\begin{abstract}
This text presents a reflection on the roles that conservator-restorers may play within the context of the disaster risk reduction efforts that Europe currently dedicates to Cultural Heritage assets. Besides discussing some aspects related to the contribution of the discipline proper to the disaster risk management of these assets, arguments are made for an increased engagement of the Conservation-Restoration private sector in research and development actions aimed at more integrated decision-making processes in the conservation of cultural property. Within this scope, the role and experience of Nova Conservação as one of the twenty partners of the Horizon 2020-funded project STORM are briefly reported.
\end{abstract}

\section{Keywords}

Built Heritage

Disaster risk reduction

Conservation-Restoration

Public-private partnerships

Project STORM

Roman ruins of Tróia
Percursos possíveis para a Conservação e Restauro na gestão dos riscos do Património Construído: parcerias público-privadas em projectos de I\&D (Projecto STORM)

\section{Resumo}

O presente texto constitui uma reflexão sobre os papéis que o conservador-restaurador pode desempenhar no contexto dos esforços de redução dos riscos de desastres que a Europa dedica actualmente à protecção de bens patrimoniais. Além de se discutirem alguns aspectos relacionados com a contribuição da disciplina propriamente dita para a gestão dos riscos de desastres que ameaçam estes bens, são apresentados argumentos a favor de um crescente envolvimento do sector privado da Conservação e Restauro em acções de investigação e desenvolvimento, com o objectivo último de promover processos de tomada de decisão mais integradores no âmbito da conservação de Património Cultural. Neste contexto, apresenta-se ainda uma breve descrição do papel e experiência da Nova Conservação como um dos vinte parceiros do projecto STORM, financiado ao abrigo do programa Horizonte 2020.

\section{Palavras-chave}

Património Construído

Redução dos riscos de desastres

Conservação e Restauro Parcerias público-privadas Projecto STORM

Ruínas romanas de Tróia 


\section{Introduction}

In the particular context of Built Heritage, the main disaster risk reduction responsibilities obviously fall upon the public sector, and especially in its emergency and cultural heritage authorities; in turn, the voluntary sector (non-governmental organizations, NGOs) may provide invaluable assistance in the management of such risks. Yet the contributions of the conservation and restoration private sector in the context of disasters occurring on Built Heritage assets - and distinctly to what happens for Museum objects - are generally still very limited to the recovery and/or restoration of the affected buildings, quite downstream within the overall management process. However, and following current paradigms that emphasize the importance of prevention and disaster preparedness, the private sector operating in the conservation and restoration of Built Heritage can provide relevant input; particularly in the developing and/or providing of instruments to support a more integrated understanding and management of materials in their contexts, e.g. actions of maintenance, monitoring, training, etc.

Very recently, the European Commission decided to grant almost 14 million Euros to fund two projects dedicated to the mitigation of the impacts of natural disasters and climate change on Cultural Heritage assets. This effort is hardly surprising considering the rate of destruction that these events may inflict upon our patrimony, which is increasingly regarded across Europe as pivotal for the identity and cohesion of societies. Both initiatives bring together public, non-profit and private institutions, reflecting the emphasis given in Horizon 2020 (henceforth H2020) to projects promoting a closer relationship between the obtaining of research and development (R\&D) results and their implementing in the European business community, particularly at the level of small and medium enterprises (SMEs).

Project STORM (Safeguarding Cultural Heritage through Technical and Organizational Resources Management) submitted one of the funded proposals, articulating the efforts of twenty partners, spread across seven different countries, providing expertise in areas ranging from civil protection to diverse sensor technologies; from meteorology to archaeology; from seismology to conservation. Within the scope of these two European project consortia, there is only one conservation-restoration company (Nova Conservação) participating as partner. Along the following sections, the role of conservation-restoration in the scope of Disaster Risk Reduction for the heritage sector is discussed, with emphasis on the possible contributions of a conservation-restoration SME as partner of a European research \& innovation project.

\section{Disaster risk reduction in the context of Built Heritage conservation}

Disaster risk reduction (DRR) is a designation that denounces the growing awareness of the need for a stronger focus on preventive approaches that presides over disaster risk management strategies today. DRR may be defined as encompassing two key elements:

- Risk reduction, which "refers to efforts to limit risks due to hazardous situations. This can be achieved by good prevention" [1, p. 171].

- Disaster management, which "signifies the need to reduce or limit the resulting damages caused by a disaster. This can be achieved by good preparedness, an efficient disaster or crisis management system and an effective recovery process" [1, p. 171].

In the past decades, the application of risk management methodologies, among which DRR is included, to Cultural Heritage assets has been developed along two main spheres: the preventive conservation of objects in museum contexts; and the management of the impact of disasters on architectural heritage. In more recent years, the management of risks to the Built Heritage from a preventive conservation perspective has also been gaining momentum, with advances being made mainly in the area of analysis and monitoring of environmental impacts, for subsequent integration in methodologies for the prioritization of conservation interventions, such as risk maps.

Regarding disaster risks specifically, the UNESCO Intergovernmental Committee for the Protection of the World Cultural and Natural Heritage explicitly "recommends that States Parties include risk preparedness as an element in their World Heritage site management plans and training strategies" [2, art.118]. In turn, the 2010 revision of the ICOMOS New Zealand Charter clearly states the need for assessing the risks pressing cultural heritage places, listing natural disasters and human-induced threats as main risks for the integrity of heritage values; these risk assessments are to be complemented by "a risk mitigation plan, an emergency plan, and/or a protection plan [, which] should be prepared, and implemented as far as possible, with reference to a conservation plan" [3, p. 8]. ICOMOS has also been publishing "Heritage at Risk" (H@R) reports since 2000, along with the proceedings from the dedicated symposia "Cultural Heritage and Natural Disasters - Risk Preparedness and the Limits of Prevention" and the two "Tangible Risks, Intangible Opportunities: Long-term Risk Preparedness and Responses for Threats to Cultural Heritage", where field applications of risk management strategies against natural and human-caused disasters are presented, so that lessons may be learnt and a body of knowledge is built.

Likewise, ICCROM was among the first institutions to propose a document on risk preparedness, applicable to World Cultural Heritage [4], and endorsed by UNESCO and ICOMOS; this manual was complemented in 2010 by the publication, together with UNESCO World Heritage Centre (UNESCO-WHC), of, among others, "Managing Disaster Risks for World Heritage" [5], which guides site managers through the development of a disaster risk management plan. Finally, a special mention is due to the 
recent "Cultural First Aid" ICCROM-The Smithsonian Institution initiatives [6], which work on building the resilience of heritage communities via comprehensive training programmes on the disaster preparedness and, especially, response phases.

\section{The urgency of a (practical) paradigm shift}

Albeit the shift of focus from remedial to preventive conservation has been strongly encouraged in the past decades, its implementation in practice is still somewhat limited in what concerns architectural heritage. Several reasons may be behind these apparent implementation difficulties, including the scale of the objects and the implicated resource needs, adding to the "over-riding preoccupation with the fundamental utility of heritage buildings" mentioned by Stovel [4, p. 1].

A brief analysis of the investment made in the conservation of the archaeological structures of the Roman ruins of Tróia, in which Nova Conservação has been directly involved in the past years, may be illustrative at this point. The current site manager, Tróia Resort, was charged with the preservation and valorisation of the Roman ruins in 2005, a responsibility all the more considerable given the state of abandonment that the structures had reached and their consequent numerous fragilities. Rising to the challenge of conserving the ruins implied a substantial effort in human, time and financial resources, starting which the appointing of a permanent team of archaeologists, in charge of the ongoing research and of the site management proper; and followed by the landscape project, arguably the most visible result of this investment, which greatly improved the site's visiting and fruition features.

Figure 1 presents the amounts spent by Tróia Resort in the conservation-restoration of different site

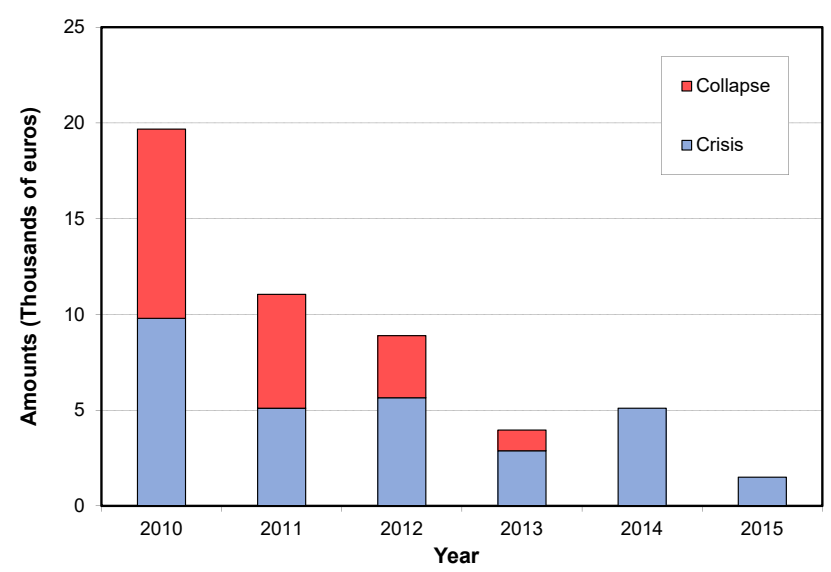

Figure 1. Amounts invested in the conservation of stone structures of the Roman Ruins of Tróia carried out by Nova Conservação between 2010 and 2015: in the first years, the spending was as much dedicated to the resolution of partial collapses as it was to crisis (pre-collapse) situations; over the years, collapses have been prevented, and the efforts are now directed at preventing crises from becoming collapses. structures between 2010 and 2015, carried out by Nova Conservação. In 2010, the year of the valorisation project set up by the site manager, the investment was by far the largest. Nevertheless, apart from the protective covering and/or reburial of a few structures in that year; and the photogrammetric and laser scanning surveys of some of the site areas (none of which executed by Nova Conservação, and hence not shown in the diagram), the investment in preventive conservation has been negligible. The conservation-restoration of the stone structures of the Tróia site has been largely based on five-year plans that attempt to address the most pressing problems given the restrictions in the budget made available for the conservation of the site yearly. This translates into identifying partial collapse and pre-collapse (crisis) situations, so that priority is given to the treatment of the most serious decay processes, and to partial reconstructions where necessary, aiming at preserving the scientific and documental values of the original construction materials and techniques to the largest extent possible.

These yearly conservation investments are entirely due to the efforts and advocating of the archaeologists who manage the ruins, consistently demonstrating their awareness and receptivity regarding the conservation needs of the site; they are, nevertheless, still insufficient for the complete halting of emergency/crisis situations (outside of catastrophic events) and the implementing of an overtly preventive strategy. In a site where significance is largely determined by scientific and documental values, the importance of preserving the original construction material and techniques, as well as all signs and traces of historical use, cannot be overstated; which makes preventive conservation approaches all the more critical.

\section{The contribution of the conservation- restoration discipline}

As pointed out vis-a-vis the Sendai Framework (see next section), DRR “is not a sector in and of itself" [7, p. 6], and therefore, in what concerns its application, "It is for policy makers and practitioners to develop and implement sector instruments, policies, programmes, guidelines, standards as well as business practices" [7, p. 6]. In the conservation sector, "practitioners" (and, ideally, "policy makers") should evidently include conservator-restorers, who may aid not only in enhancing the site's resilience, via direct and indirect conservation actions, but also in enhancing the coping capacity of the heritage community, via training and dissemination activities.

Conservation is all about "managing change" $[8, \mathrm{p}$. 71]; and conservator-restorers are specifically trained to accompany transformation in heritage objects, which implies articulating knowledge on the evolution of heritage materials in their contexts with the aspirations of their respective (present and future) stakeholders. From this background, and in the specific framework of DRR, the contribution of conservation-restoration may prove 


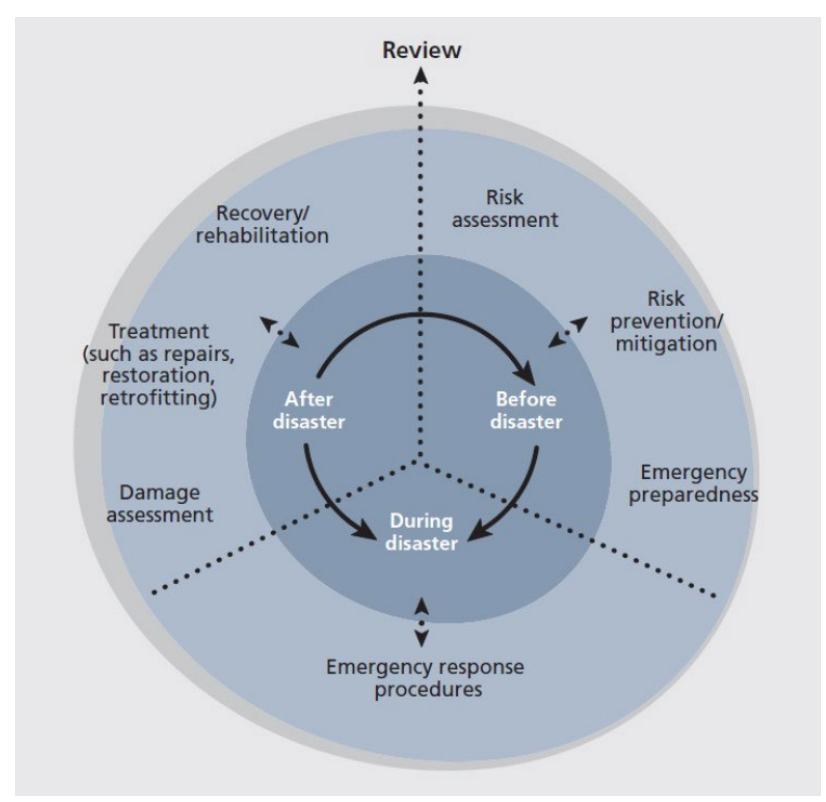

Figure 2. Disaster risk management cycle, as proposed by UNESCO-WHC et al. [5].

key in: (i) understanding heritage risks; (ii) developing procedures and methodologies to help mitigate and/or counteract the impacts of different hazards; (iii) reacting to catastrophic scenarios; (iv) creating monitoring protocols and consequent crisis management models (for slow- or rapid-onset crisis); (v) "build back better" (a DRR priority), which in heritage contexts amounts to recovery actions that promote the object's and the concerned community's resilience; and (vi) in making good practice recommendations.

UNESCO-WHC et al. have proposed that the heritage risk management cycle may be represented by the phases described in Figure 2. From this scheme, it is suggested here that the conservation-restoration discipline may contribute to heritage DRR in all of the processes listed in Table 1, i.e., across the entire DRR action spectrum.

\section{Public-private partnerships in the context of DRR}

\section{The fostering of PPPs within DRR}

The Sendai Framework for Disaster Risk Reduction 2015-2030 [9] is the United Nations current guiding charter for the development and enactment of disaster risk management policies and strategies by member states at national, regional and local levels. The Sendai Framework was built upon the experience gained with the implementation of diverse disaster risk management instruments, and particularly upon the learnings ensuing from the application of the previous UN dedicated framework, the Hyogo Framework for Action [7]. Based on the "lessons learned, gaps identified and future challenges" drawn from the Hyogo Framework, the Sendai Framework highlights the need for "the public and private sectors and civil society organizations, as well as academia and scientific and research institutions, to work more closely together and to create opportunities for collaboration" [9, par. 7].

In fact, one of the core principles of Sendai is that "disaster risk reduction requires an all-of-society engagement and partnership" [9, par. 19] (emphasis added), and this multilevel societal commitment is pervasive throughout the whole text: "disaster risk reduction and management depends on coordination mechanisms within and across sectors and with relevant stakeholders at all levels, and it requires the full engagement of all State institutions of an executive and legislative nature at national and local levels and a clear articulation of responsibilities across public and private stakeholders, including business and academia, to ensure mutual outreach, partnership, complementarity in roles and accountability and followup" [9, par. 19] (emphasis added).

The recommendations to achieve the different Sendai priorities again refer to an increased commitment of the private sector as fundamental, namely highlighting the need to:

\section{Table 1}

Possible contributes of the Conservation-restoration discipline in each of the DRR phases

\begin{tabular}{|c|c|c|}
\hline DRR phase & Possible contributes of Conservation-restoration & \\
\hline Risk Assessment & $\begin{array}{l}\text { - In the identification, analysis and assessment of Hazards; vulnerability; exposure } \\
\text { - In the Risk Evaluation process }\end{array}$ & \multirow{5}{*}{$\begin{array}{l}\text { In the } \\
\text { documentation } \\
\text { of the whole } \\
\text { process }\end{array}$} \\
\hline $\begin{array}{l}\text { Prevention \& } \\
\text { Mitigation }\end{array}$ & $\begin{array}{l}\text { - In the implementing of maintenance and/or preventive conservation actions/plans; } \\
\text { - In the training or consultancy actions in preventive conservation }\end{array}$ & \\
\hline Preparedness & $\begin{array}{l}\text { - In the developing of emergency-response plans; } \\
\text { - Recommending material and human resources emergency needs }\end{array}$ & \\
\hline Response & - In several steps of Cultural First Aid, as defined by ICCROM \& The Smithsonian Institution & \\
\hline Recovery & $\begin{array}{l}\text { - In conservation \& restoration } \\
\text { - In the returning of salvaged assets } \\
\text { - In monitoring and reviewing the different processes } \\
\text { - In informing the public }\end{array}$ & \\
\hline
\end{tabular}


- foster cooperation and partnerships between the scientific and technological community, academia and the private sector in research, development and dissemination efforts (see, for instance, par. 25 and 31 [9]);

- encourage the private sector engagement in DRR research and innovation; technological development; knowledge sharing and dissemination; and development of normative frameworks and technical standards (under the guidance of the public sector; see, for instance, par. 36 [9]).

It can thus be said that, (at least) in the particular scope of DRR, space is increasing for the private sector to not only share its expertise and perspective, but also to venture further into $R \& D$ and dissemination initiatives.

\section{The fostering of PPPs at European level}

The critical importance of SMEs in the sustaining and development of economies in the European space is institutionally acknowledged - the European Commission Annual Report on European SMEs 2015/2016 illustratively begins with the sentence "SMEs form the backbone of the EU28 economy" [10, p. 1]. Among other things, this implies that the competitiveness of the EU28 economy relies heavily upon the competitiveness of its SMEs, which must therefore be furthered as much as possible. Moreover, "since the competitiveness of European SMEs in the global arena largely depends on their ability to innovate, unlocking the innovation potential of SMEs becomes pivotal to fostering growth and jobs in Europe" [11, p. 1].

Advancing European competitiveness via investing on its capacity for innovation is the primary goal of the Horizon 2020 programme [12]. In line with the aforementioned recognition of the key role of SMEs, financial instruments were developed within H2020 aimed at an increased participation of SMEs in R\&D, both directly (via the SME instrument) and indirectly (via the financing of projects in consortia submitted within larger calls): in short, "more than $10 \%$ of the total Horizon 2020 budget are expected to support research and innovation activities carried out by SMEs" [11, p. 2]. Even though some obstacles that may be preventing a wider SME involvement in H2020 have been noted, the tendency should be for Europe to support an ever-growing participation of SMEs in R\&D, through H2020 and other financial instruments [11].

\section{Cultural Heritage DRR in the EU: the application of Sendai}

The "all-of society engagement" mentioned in Sendai as critical for the design and application of DRR measures and policies became one of the (four) Key Areas of the European Commission Action Plan for the implementation of the Sendai Framework [13]. Nevertheless, it is under Key Area 4, "Enhancing disaster preparedness for effective response and to 'Build Back Better' in recovery, rehabilitation and reconstruction" (which concerns the implementation of Sendai Priority 4), that the European initiatives regarding the application of DRR for cultural heritage protection are previewed, following the paragraph 30(d) of the Sendai Framework [13, pp. 14-16]. These initiatives, intended to "develop good practices on the integration of cultural heritage in the national disaster risk reduction strategies to be developed by EU Member States" [13, p. 4], include:

- assessing the risks and develop prevention measures for the safeguarding of cultural heritage from the impacts of natural disasters and human-caused threats, as per the recommendations of the Work Plan for Culture [14];

- the Horizon 2020 DRS-11-2015 call on "Disaster Resilience and Climate Change topic 3: Mitigating the impacts of climate change and natural hazards on cultural heritage sites, structures and artefacts" [15], under which two international projects, HERACLES and STORM, were chosen for financing and are currently underway.

Other European initiatives on improving the resilience of cultural heritage sites against disaster risks are currently ongoing [16], asserting the current relevance of the topic, and mirroring the shift from remedial to preventive approaches both in DRR strategies and in the heritage conservation discipline. In the context of the current text, presenting the perspective of a conservation-restoration SME collaborating in this field as a $\mathrm{H} 2020$ project partner, the STORM project will be discussed further.

\section{Project STORM}

\section{Aim and goals}

Ultimately, the aim of project STORM is to develop instruments to increase the resilience of heritage objects (including sites) against the impacts of natural disasters and climate changes. This aim is to be pursued along three main dimensions: Prevention; Intervention; and Policies, planning and processes, within which the objectives listed in Table 2 [17] were envisaged.

As may be inferred from the table, STORM intends to provide both technological and procedural tools to support decision makers faced with crisis and disaster situations during the DRR phases of prevention, preparedness, response and recovery; a disaster risk management approach will be followed as a means to promote more holistic and integrative decision-making processes [18]. The tools to be developed within STORM notably include: normative proposals and technical guidelines covering different phases and operational sectors intervening in heritage assets; low-cost sensors and software tools to support early detection and followup of emergency situations; and a collaborative platform for knowledge sharing among different actors to promote 
Table 2

Objectives of STORM for each of the foreseen project dimensions (adapted from [17])

\begin{tabular}{|c|c|c|}
\hline Prevention & Intervention & Policies, planning and processes \\
\hline \multirow{4}{*}{$\begin{array}{l}\text { OBJ1: Select, evolve and } \\
\text { integrate environmental } \\
\text { assessment methodologies and } \\
\text { services } \\
\text { OBJ2: Define and implement } \\
\text { a supporting service for the } \\
\text { mitigation of natural hazards } \\
\text { and assessment/ management } \\
\text { of threats }\end{array}$} & $\begin{array}{l}\text { OBJ3: Survey and diagnose resorting to cost effective, } \\
\text { non-invasive and non-destructive methods and } \\
\text { processes relating materials properties, particular } \\
\text { environmental conditions, and profile of cultural } \\
\text { heritage sites }\end{array}$ & $\begin{array}{l}\text { OBJ7: Propose adaptations and changes } \\
\text { in existing policies and government } \\
\text { processes, based on the acquired } \\
\text { knowledge }\end{array}$ \\
\hline & $\begin{array}{l}\text { OBJ4: Define and implement models and services for } \\
\text { generating and managing a situational picture based on } \\
\text { data collected by physical and human sensors }\end{array}$ & \multirow[t]{3}{*}{$\begin{array}{l}\text { OBJ8: Provide cost analysis for site } \\
\text { protection against natural hazards } \\
\text { managed by the STORM data analytics } \\
\text { tools }\end{array}$} \\
\hline & $\begin{array}{l}\text { OBJ5: Provide methodologies, practices and software } \\
\text { tools for more reliable maintenance, restoration and } \\
\text { long-term conservation }\end{array}$ & \\
\hline & $\begin{array}{l}\text { OBJ6: Define a collaboration and knowledge-sharing } \\
\text { framework for the community of stakeholders }\end{array}$ & \\
\hline
\end{tabular}

crisis management on heritage sites in an integrated and sustainable manner.

\section{Project architecture}

The proposed instruments will be developed on the basis of the results (i) of a survey of heritage agents in all partner countries (in progress), to identify methodological and/or procedural (regulatory) needs in the various phases of asset intervention pre- and postcrisis; (ii) of the readings of the various sensors to be installed in the pilot sites, according to the specific risk scenarios developed for each site (in progress). These sensors include not only legacy systems, e.g. thermohygrometers, but also instruments to be developed or tailored for their specific application within the project, including: wireless acoustic sensor networks (WASN) for detecting fire, flood and infestations; drones equipped with high resolution cameras and light detection and ranging (LiDAR) and/or cameras with near infrared detection and/or thermal and multispectral sensors for mapping and monitoring of structural movements and surface changes; induced fluorescence sensors for the monitoring of biological colonization; and interferometric synthetic aperture radar (InSAR), for monitoring structural changes and/or detecting seismic activity or flooding. On the other hand, technologies will be developed to enable the use of data obtained by crowdsensing, i.e., requested by internet to visitors or other users of heritage sites.

The information flows between the different project layers are depicted in Figure 3 [19], which also highlights the intended STORM outcomes: technological instruments and planning and policy recommendations for a more integrated management of the hazards affecting cultural heritage sites. Based on the heterogeneity of sites and respective contexts, STORM intends to build a knowledge platform flexible enough for site managers to adapt to the specificities of each site and its impending threats; grounded on information and results drawn from a risk-management based approach, supported by cost-effective monitoring and/or earlywarning technologies.

\section{The role of Nova Conservação}

In pursuit of the aforementioned objectives, STORM convenes partners from a wide range of areas [20], bringing together experts from archaeology, meteorology, seismology, different sensor technologies, conservation and restoration, civil protection; and cultural heritage protection authorities, both at governmental level and at site management level, including of course the institutions behind the pilot sites on which STORM tools will first be tested: the Roman ruins of Tróia (Portugal); the baths of Diocletian, in Rome (Italy); the fortress and old centre of Rethymno, in Crete (Greece); the grand theatre of

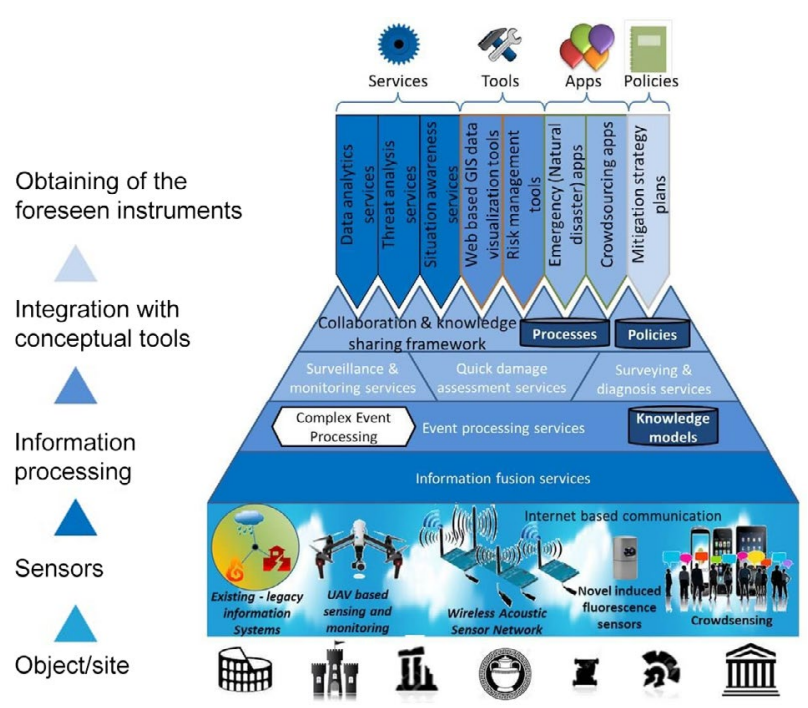

Figure 3. Project STORM architecture, highlighting the information flows of the sensors that will be used (in the base) to the instruments that will be developed in the scope of the project (at the top). Adapted from [19]. 

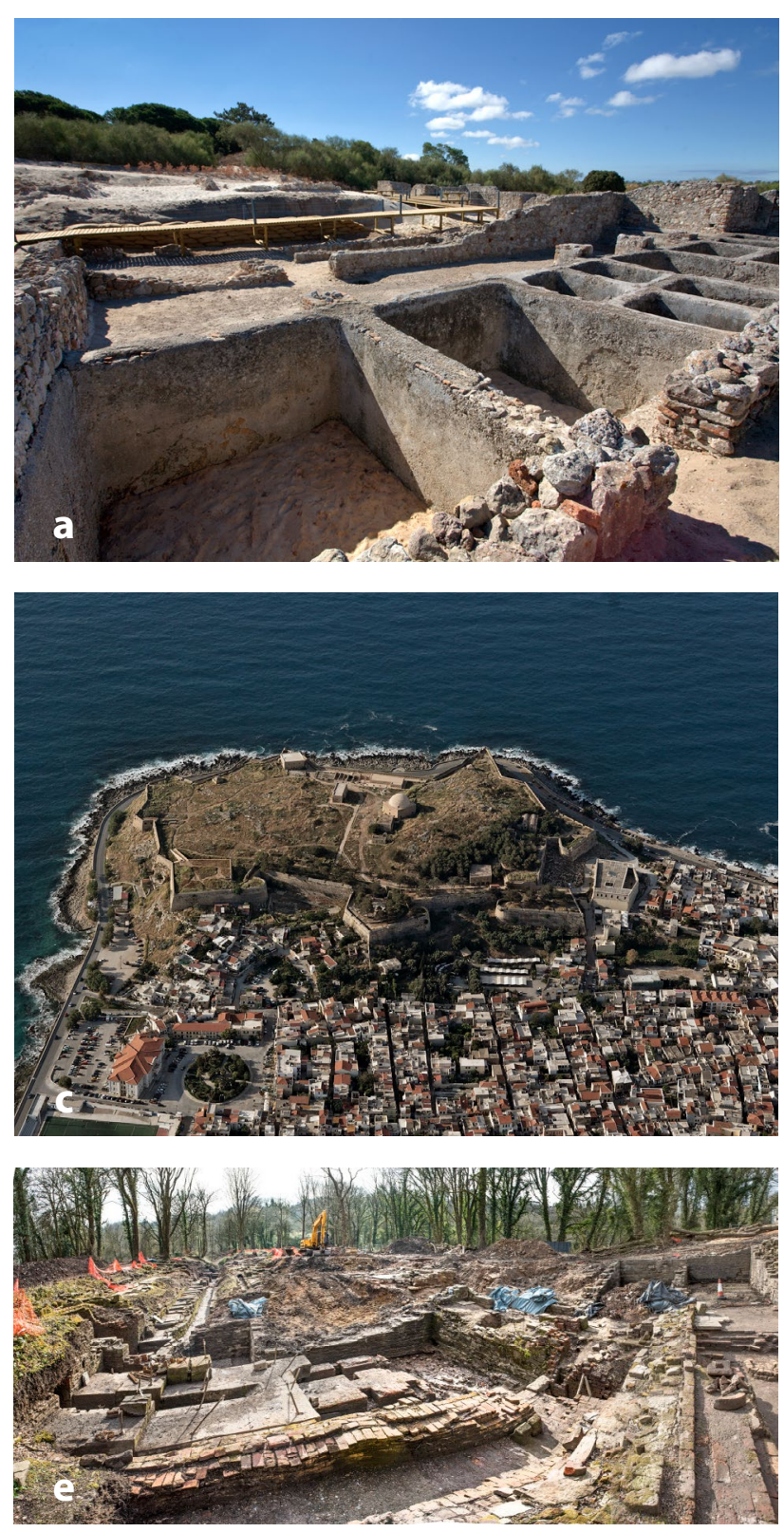

Ephesus (Turkey); and the archaeological site of Mellor (UK) (Figure 4) [21].

In this project consortium, Nova Conservação is one of the main contributors to the conservation-restoration sphere, offering recommendations and strategies for its proper integration and implementation, not only in the scope of STORM, but also within the future solutions that the project intends to propose for a more comprehensive and sustainable safeguarding of cultural heritage objects. Given the training and experience of its collaborators, Nova Conservação is able to propose an understanding of the objects that allows identifying needs, priorities and objectives for their preservation in pre- and post-disaster contexts; thus supporting the strengthening of methodologies aimed at a more integrated management of the diverse risks affecting built heritage assets. For these reasons, Nova Conservação is expected to make contribu-
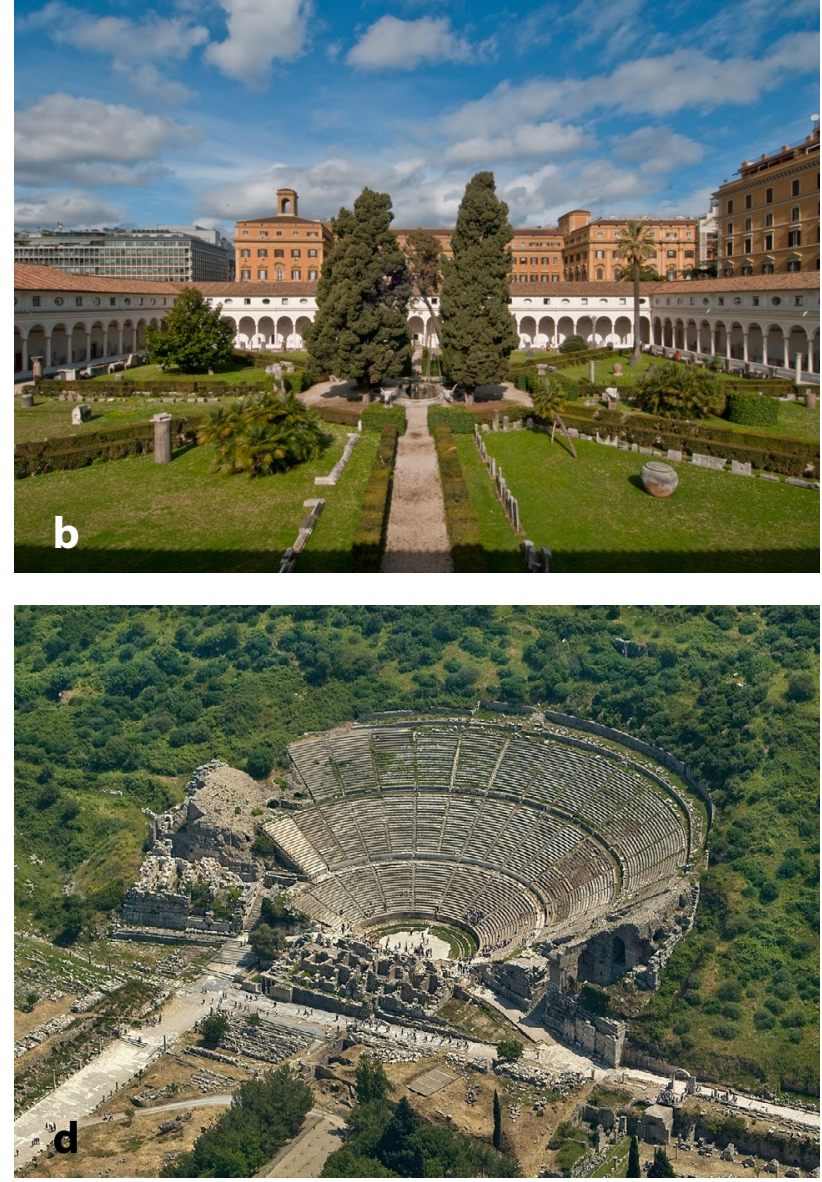

Figure 4. Project STORM pilot sites: a) Roman ruins of Tróia b) Diocletian baths; $c$ ) fortress and old centre of Rethymno; $d$ ) grand theatre of Ephesus; $e$ ) Mellor archaeological site. Source: [21].

tions within most of the work packages previewed (and underway) within STORM, as depicted in Figure 5 [22].

Thus far, Nova Conservação was able to contribute heavily to the project's frame of reference, including the identification and characterization of the relevant processes and actors involved, and the tailoring of DRR to the Built Heritage field. In addition, Nova Conservação is one of the technical advisors to the Tróia ruins, assisting not only in the identification of the main threats facing the site and its respective exposure and vulnerability features, but also in the definition of the actions required to enhance the site's resilience to natural disasters and climate change. Nova Conservação will be the main partner advising on specific conservation actions that may mitigate the impact of environmental risks upon the archaeological structures of Tróia.

As conservator-restorers, it is our perspective that the enhancement of the resilience of heritage sites against the hazardous impacts critically relies not only in having adequate emergency preparedness and response systems in place; but also in identifying and implementing prevention and mitigation measures, dictated by a deep understanding of the particular conditionings of each site 


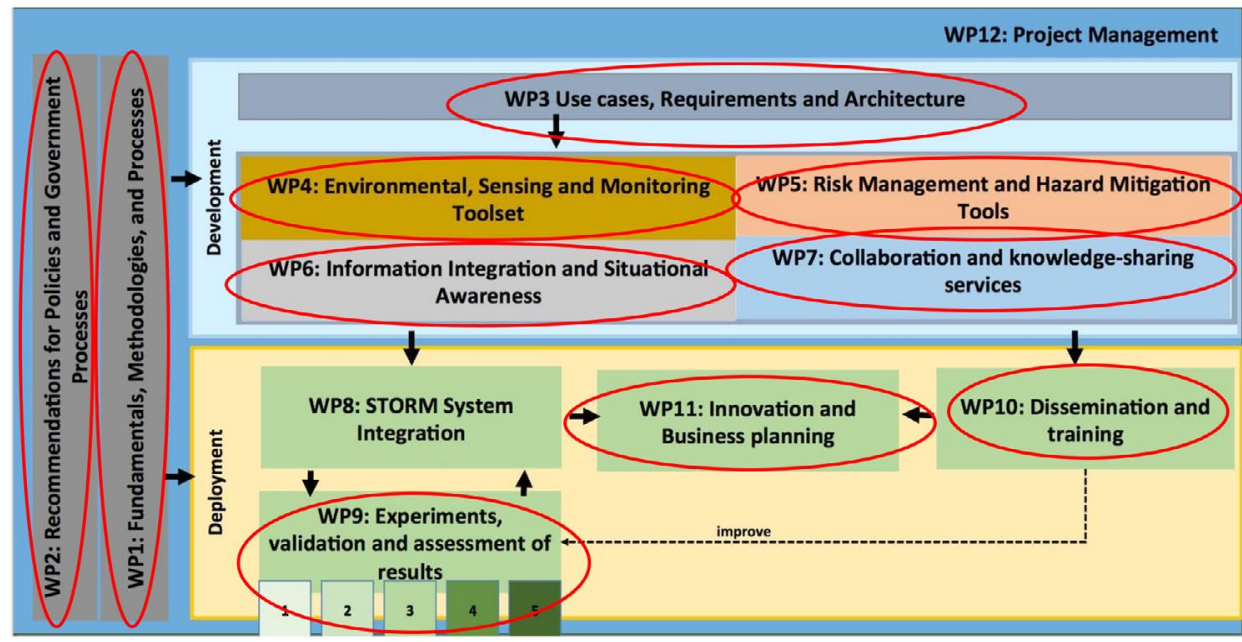

Figure 5. Work plan of project STORM, emphasizing the participation of Nova Conservação across the different project areas (work packages). Adapted from [22].

and framed within a holistic management context, where maintenance strategies should feature prominently.

\section{Conclusions}

The fact that disaster risk reduction must ensue from an all-of-society effort holds true in what concerns the Cultural Heritage sector, particularly when considering that the paradigm shift from remedial to preventive conservation approaches stills needs to gain a wider recognition and application at practical level.

The conservation-restoration discipline, being relatively new, is not always given the necessary space in the definition of decision-making recommendations, methodologies or strategies, especially in the scope of Built Heritage conservation, but it can, in fact, add a relevant contribution at this macro-level in the bridging of the concerns of site managers, the results obtained via materials research, and the conservation needs of the objects proper. This dialogue articulation, as well as the advocating for the present and, specially, the future significance of heritage objects is where conservationrestoration may make a difference, thus promoting more integrated conservation processes.

To involve the conservation-restoration private sector at the methodology-development stages should promote a faster transfer of the acquired (and duly validated) knowledge and tools into practice, which, in turn, should relevantly assist in endowing the heritage sector with more effective capacities to cope with ever-pressing risks.

\section{Acknowledgements}

The reviewing of the data related to the conservation works in the Tróia site, as well as the permission to use it here, are hereby gratefully acknowledged to Inês Vaz Pinto, lead archaeologist and manager of the Roman ruins of Tróia. Further thanks are due to Isabel Raposo Magalhães, for her invite to present these reflections in the International Conference «Cultural Heritage: Disaster Preparedness, Response and Recovery» and helpful suggestions.

Project STORM has received funding from the European Union's Horizon 2020 research and innovation programme under grant agreement no. 700191.

\section{References}

1 Ammann, W. J., 'Disaster risk reduction', in Encyclopedia of Natural Hazards, ed. P. Bobrowsky, Springer Science+Business Media, Dordrecht (2013) 170-175.

2 Operational Guidelines for the Implementation of the World Heritage Convention, UNESCO, Paris (2015), http://whc. unesco.org/document/137843 (accessed 2016-08-10).

3 ICOMOS New Zealand Charter for the Conservation of Places of Cultural Heritage Value, ICOMOS New Zealand, Auckland (2010), http://www.icomos.org/charters/ ICOMOS_NZ_Charter_2010_FINAL_11_Oct_2010.pdf (accessed 2016-08-10).

4 Stovel, H., Risk Preparedness: a Management Manual for World Cultural Heritage, ICCROM, Rome (1998), http://www.iccrom.org/ifrcdn/pdf/ICCROM_17_ RiskPreparedness_en.pdf (accessed 2016-06-07).

5 Managing Disaster Risks for World Heritage, UNESCO World Heritage Centre, Paris (2010), http://whc.unesco.org/ en/managing-disaster-risks/ (accessed 2016-06-10).

6 First Aid to Cultural Heritage in Times of Crisis: A Framework Document, ICCROM-The Smithsonian Institution (2016), http://www.iccrom.org/wp-content/ uploads/1_FAC-2016_Framework-document.pdf (accessed 2016-10-06).

7 Reading the Sendai Framework for Disaster Risk Reduction 2015-2030, UNISDR, Geneva (2015), http://www.unisdr. org/files/46694_readingsendaiframeworkfordisasterri.pdf (accessed 2016-10-13).

8 Conservation Principles, Policies and Guidance, English Heritage, London (2008), https://content.historicengland. org.uk/images-books/publications/conservation-principlessustainable-management-historic-environment/conservatio 
nprinciplespoliciesguidanceapr08web.pdf/ (accessed 201607-14).

9 Sendai Framework for Disaster Risk Reduction. 20152030, United Nations Office for Disaster Risk Reduction, Geneva (2015), http://www.preventionweb.net/files/43291_ sendaiframeworkfordrren.pdf (accessed 2016-10-13).

10 Muller, P.; Devnani, S.; Julius, J.; Gagliardi, D.; Marzoc, C., Annual Report on European SMEs 2015/2016: SME Recovery Continues, European Commission, Brussels (2016), https://doi.org/10.2873/76227.

11 Simonelli, F., 'Is Horizon 2020 really more SME-friendly? A look at the figures' (2016), in CEPS, Brussels, https:// www.ceps.eu/publications/horizon-2020-really-more-smefriendly-look-figures (accessed 2016-10-18).

12 'What is Horizon 2020?', in European Commission, Brussels, https://ec.europa.eu/programmes/horizon2020/en/ what-horizon-2020 (accessed 2016-09-15).

13 'Action plan on the Sendai framework for disaster risk reduction. 2015-2030' (2016), in European Commission, Brussels, http://ec.europa.eu/echo/sites/echo-site/files/1_en_ document_travail_service_part1_v2.pdf (accessed 2016-1013).

14 'Work plan for culture. 2015-2018' (2014), in Council of the European Union, Brussels, http://data.consilium.europa.eu/ doc/document/ST-16094-2014-INIT/en/pdf (accessed 201610-13).

15 'DRS-11-2015 - Disaster resilience \& climate change topic 3: mitigating the impacts of climate change and natural hazards on cultural heritage sites, structures and artefacts' (2015), in CORDIS, http://cordis.europa.eu/programme/ rcn/665083_en.html (accessed 2017-04-08).

16 'Abstracts of selected EU research and innovation projects' (2016), in European Commission, Brussels, https://ec.europa.eu/research/environment/index. cfm? \& e ventcode $=0$ A F B 78 E A - D 0 F 2 - C 50 B CC7D053E985B0D5A\&pg=events (accessed 2017-01-11).
17 'Objectives', in STORM, http://www.storm-project.eu/overview/objectives/ (accessed 2017-04-08).

18 'Architecture', in STORM, http://www.storm-project.eu/ overview/architecture/ (accessed 2017-04-08).

19 Revez, M. J.; Delgado Rodrigues, J.; Proença, N.; Lobo de Carvalho, J. M.,: Coghi, P.; Capua, M. C.; Santamaria, U.; Boi, S.; Perossini, F., 'O risco como ferramenta conceptual de uma gestão integrada da mudança: a perspectiva do projecto STORM', in Congresso Ibero-Americano Património, suas Matérias e Imatérias, eds. M. Menezes, J. Delgado Rodrigues, \& D. Costa, LNEC, Lisboa (2016).

20 'Partners', in STORM, http://www.storm-project.eu/partners/ (accessed 2017-04-08).

21 STORM, http://www.storm-project.eu (accessed 2017-04$08)$.

22 'Workplan', in STORM, http://www.storm-project.eu/overview/workplan/ (accessed 2017-04-08).

Received: 2017-01-19

Accepted: 2017-03-17

Online: 2017-04-09

This work is licensed under the Creative Commons Attribution-NonCommercial-NoDerivatives 4.0 International License. To view a copy of this license, visit http://creativecommons.org/licenses/by-nc-nd/4.0/deed.en. 